\title{
PROFIL MAHASISWA JURUSAN KOMPUTER PADA KETERAMPILAN BERPIKIR KRITIS DAN KREATIF
}

\author{
Karmila Suryani $^{1}$, Sukardi ${ }^{2}$, Khairudin ${ }^{3}$, Dewi Sasmita ${ }^{4}$, \\ Ade Fitri Rahmadani ${ }^{5}$ \\ 1,5Pendidikan Teknik Informatika dan Komputer Universitas Bung Hatta, \\ Jalan Bagindo Azizcha, Aia Pacah, Padang \\ ${ }^{2}$ Teknik Elektro Univesitas Negeri Padang, Jalan Prof. Dr. Hamka Air Tawar, Padang \\ ${ }^{3}$ Pendidikan Matematika Universitas Bung Hatta, Jalan Bagindo Azizcha, Aia Pacah, Padang \\ ${ }^{4}$ Tadris Kimia IAIN Batu Sangkar, Jalan Sudirman Kuburajo, Lima Uaum, Tanah Datar \\ 1e-mail: karmila.suryani@bunghatta.ac.id
}

\begin{abstract}
Abstrak
Penelitian bertujuan untuk mendeskripsikan profil keterampilan berpikir kritis dan kreatif mahasiswa jurusan komputer di Kota Padang. Metode penelitian yang digunakan adalah penelitian deskriptif. Data dikumpulkan melalui kuisioner yang dibuat menggunakan google form kemudian disebarkan kepada responden penelitian yang berjumlah 115 mahaiswa. Teknik analisis data yang digunakan yaitu analisis deskriptif dengan menggunakan persentase per indikator. Hasil penelitian menunjukkan bahwa keterampilan berpikir kritis mahasiswa tergolong rendah pada indikator memberikan penjelasan lebih lanjut dan menarik kesimpulan, serta keterampilan berpikir kreatif untuk berpikir secara lancar dan orisinil mahasiswa masih rendah.
\end{abstract}

Kata Kunci: keterampilan berpikir kritis, keterampilan berpikir kreatif, profil mahasiswa.

\begin{abstract}
The research aimed to describe the critical and creative thinking skills profiles of students majoring in computer in the city of Padang. The research method used descriptive research. Data were collected through a questionnaire made using google form and then distributed to 115 respondents. The data analysis technique used descriptive analysis using percentages per indicator. The results showed that the students' critical thinking skills were low on the indicators of providing further explanation and drawing conclusions, and the students' creative thinking skills to think fluently and originally were still low.
\end{abstract}

Keywords: critical thinking skills, creative thinking, students profile.

\section{PENDAHULUAN}

Perkembangan Revolusi Industri 4.0 mengharuskan mahasiswa memiliki kemampuan berpikir kreatif (creativity), berpikir kritis, dan pemecahan masalah (critical thinking and problem solving), berkolaborasi (collaboration), dan berkomunikasi (communication) untuk membekali diri sehingga dapat menghasilkan sebuah inovasi (Lin, dkk., 2018; Singh, 2018; Sing dan Kong, 2017). Berpikir kritis dan kreatif adalah salah satu dari kunci keberhasilan mahasiswa, oleh karenanya pemerintah melalui sistem pendidikan berusaha untuk 
meningkatkan individu yang mampu untuk bertanya, berpikir kritis, sensitif, berpartisipasi, memiliki kemampuan memecahkan masalah, dan memiliki pengetahuan serta mampu berkomunikasi secara efektif (Aun dan Kaewurai, 2017). Berdasarkan pendapat tersebut, maka dapat disimpulkan bahwa perguruan tinggi sebagai tempat mewujudkan sistem pendidikan yang baik perlu membekali mahasiswanya agar terlatih untuk berpikir kritis dan kreatif.

Keterampilan berpikir kritis dan kreatif mahasiswa tumbuh dengan baik di berbagai negara melalui pembinaan terhadap dosen sebagai fasilitator dalam rangka mewujudkan kemampuan tersebut (Harris dan deBruin, 2018; Welter, dkk., 2017; Lucas, 2016; Arpan dan Marpanaji, 2015). Pendidikan yang gemilang dapat terwujud dengan menumbuhkan dan membiasakan keterampilan berpikir kritis dalam pembelajaran melalu interaksi antara dosen dan mahasiswa (Chu, dkk., 2017; Mahanal, dkk., 2016; Sripongwiwat, dkk., 2016). Seorang pemikir kritis selalu memberikan pertanyan tentang asumsi, mengidentifikasi kesimpulan yang kurang jelas, menganalisis kesalahan pendapat yang tidak logis serta menelaah fakta-fakta dengan bukti-bukti yang kongkrit (Tan, 2017). Sistem pendidikan dari berbagai negara mengutamakan keterampilan berpikir kritis dan kreatif untuk meningkatkan kemampuan individu dalam menyelesaikan dan memahami kejadian di lingkunganya.

Keterampilan berpikir kritis dan kreatif diperlukan dalam pembelajaran sains termasuk komputer yang bertujuan untuk menanggapi masalah dalam masyarakat yang disebabkan oleh pengaruh perkembangan ilmu pengetahuan dan teknologi (Fatmawati, 2016; Rashid dan Muhammad, 2016). Namun fakta yang ditemukan dalam pendidikan nasional maupun internasional, kemampuan berpikir kritis dan kreatif mahasiswa masih tergolong rendah. Keterampilan berpikir kritis mahasiswa pada kategori rendah di tingkat nasional dan internasional (Hairida dan Junanto, 2018; Husamah, dkk., 2018; Fitriawan, dkk., 2016; Mahanal, dkk., 2016; Taleb dan Chadwick, 2016).

Hasil Programme for International Students Assessment (PISA) menunjukkan bahwa Indonesia berada pada peringkat 60 dari 65 negara tahun 2009, ke 64 dari 65 negara tahun 2012, dan ke 69 dari 75 negara tahun 2015, ke 
72 dari 77 negara tahun 2019 (OECD, 2019; 2016; 2014; 2010). Hasil tersebut menunjukkan bahwa mahasiswa Indonesia belum terlatih untuk berpikir kritis dan kreatif sehingga Indonesia masih berada yang rendah. Kemampuan pemecahan masalah dan keterampilan berpikir kritis merupakan seperangkat komponen, keterampilan, dan kompetensi yang terukur dalam pembelajaran (Jatmiko, dkk., 2018; Prahani, dkk., 2018; Suyidno, 2018). Selain pembelajaran di kelas, pembelajaran praktik juga membutuhkan keterampilan berpikir kritis dan kreatif, namun mahasiswa terlihat tidak kreatif dalam melaksanakan pembelajaran praktik di sekolah (Septianawati, 2019; Suprapto, 2016). Pada umumnya tidak ada perbedaan kreativitas mahasiswa yang melaksanakan pembelajaran di kelas maupun di laboratorium berdasarkan jenis kelamin (Carrasco, 2017).

Interaksi antara berpikir kritis dan kreatif dapat memberikan kontribusi pemikiran reflektif untuk prestasi akademik dan memungkinkan mahasiswa untuk menjadi lebih kritis sehingga dapat membuat perubahan percaya diri (Ghanizadeh, 2017). Prestasi akademik mahasiswa bidang komputer khususnya pada pembelajaran yang bersifat eksakta, misalnya matematika dan elektronika digital tergolong rendah. Hal tersebut terlihat dari nilai semester yang mahasiswa peroleh hanya $47 \%$ mahasiswa dengan nilai kategori baik, selebihnya mendapatkan nilai yang rendah pada kategori kurang baik. Saat proses pembelajaan di kelas, mahasiswa kesulitan dalam memberikan penjelasan yang lebih lanjut terkait dengan permasalahan yang dikemukakan. Mahasiswa hanya menunggu instruksi dari dosen dalam melaksanakan praktik. Mahasiswa kurang kritis dan kreatif dalam pembelajaran, sementara keterampilan tersebut sangat dibutuhkan. Kedua keterampilan tersebut harus dimiliki mahasiswa pada era Revolusi Industri 4.0.

Berdasarkan uraian yang telah dikemukakan, maka keterampilan berpikir kritis dan kreatif dalam menghadapi tantangan abad ke-21 sangat penting untuk dimiliki oleh mahasiswa. Hal tersebut yang menjadi alasan mengapa peneliti tertarik untuk mengetahui profil keterampilan berpikir kritis dan kreatif mahasiswa jurusan komputer di kota Padang. 


\section{METODE}

Penelitian menggunakan metode deskriptif. Data diperoleh berdasarkan kuisioner yang diserbarkan melalui google form ke mahasiswa jurusan komputer di kota Padang yaitu Universitas Bung Hatta, Universitas Putera Indonesia "YPTK", Universitas Dharma Andalas, dan Sekolah Tingggi Manajemen Informatika Komputer Indonesia. Responden yang menjadi subjek penelitian berjumah berjumlah 115 orang. Instrumen penelitian berupa kuisioner berpikir kritis dan kreatif terdiri dari 10 item untuk berpikir kritis dan 9 item untuk berpikir kreatif yang terlebih dahulu dilakukan uji validitas dan relialibilitas. Analisis validitas menggunakan uji statistik dengan Analysis Correate Bivariate diperoleh hasil bahwa dari 19 item yang diujicobakan terdapat 1 item yang tidak valid sehingga item tersebut tidak digunakan. Sementara nilai reliabiltas dari kuisioner yang sudah valid adalah 94,4\%. Sedangkan untuk melakukan analisis data digunakan analisis deskriptif dengan menggunakan persentase per indikator.

Kuisioner keterampilan berpikir kritis dibuat berdasarkan pendapat (Munandar, 2009) dengan indikator pada Tabel 1.

\section{Tabel 1 Indikator Keterampilan Berpikir Kritis}

\begin{tabular}{ll}
\hline \multicolumn{1}{c}{ Indikator } & \multicolumn{1}{c}{ Sub Indikator } \\
\hline Memberi Penjelasan & Memfokuskan pada pertanyaan; \\
Sederhana (elementary & Menganalisis argumen; \\
Clarification) & Bertanya dan menjawab pertanyaan tentang \\
& sesuatu penjelasan dan tantangan. \\
Membangun keterampilan & Mempertimbangkan kredibilitas suatu sumber; \\
dasar (Basic support) & Mengobservasi dan mempertimbangkan \\
& laporan observasi. \\
Menarik Kesimpulan & Membuat dan mempertimbangkan hasil \\
(inference) & keputusan. \\
Membuat penjelasan lebih & Mengemukakan jawaban yang lebih detail; \\
lanjut (advance clarification) & Menguraikan asumsi. \\
Strategi dan Taktik & Memutuskan satu tindakan; \\
(Strategy and tactic) & Berinteraksi dengan orang lain. \\
\hline
\end{tabular}

Indikator untuk keterampilan berpikir kreatif (Munandar, 2009) dapat dilihat di Tabel 2. 
Tabel 2 Indikator Berpikir Kreatif

\begin{tabular}{ll}
\hline \multicolumn{1}{c}{ Indikator } & \multicolumn{1}{c}{ Sub Indikator } \\
\hline Keterampilan Berpikir & Keterampilan dalam mencetuskan gagasan, \\
Lancar & jawaban, penyelesaian masalah atau pertanyaan; \\
& Keterampilan memberikan cara atau saran; \\
& Keterampilan dalam memikirkan jawaban \\
& alternatif. \\
Keterampilan Berpikir & Keterampilan dalam menghasilkan gagasan, \\
Luwes (Fleksibel) & jawaban atau pertanyan yang bervariasi; \\
& Keterampilan dalam melihat masalah dari sudut \\
& pandang yang berbeda-beda; \\
& Keterampilan dalam mencari banyak alternatif \\
& yang berbeda-beda dan berkolaborasi; \\
& Keterampilan dalam memperkaya gagasan. \\
& Kemampuan melahirkan ungkapan yang baru \\
Keterampilan Berpikir & dan unik; \\
Orisinil & Memikirkan cara yang tidak lazim dalam \\
& mengungkapkan diri sendiri; \\
& Kemampuan dalam mengkombinasi. \\
\hline
\end{tabular}

Kemampuan berpikir kritis mahasiswa dianalisis dengan persentase skor rata-rata sesuai dengan indikator dengan rumus berikut.

$$
\text { Rata }- \text { Rata }=\frac{\text { Skor total dari semua indikator }}{\text { Jumlah responden }}
$$

Penentuan persentase yang diperoleh dari masing-masing indikator dianalisis dengan rumus berikut.

$$
\text { Persentase }=\frac{\text { Skor rata-rata }}{\text { Skor maksimum }} \times 100 \%
$$

Interpretasi indikator kemampuan berpikir kritis dan kreatif mahasiswa (Ridwan, 2010) dapat dilihat di Tabel 3.

Tabel 3 Interpretasi Kemampuan Berpikir Kritis dan Kreatif Mahasiswa

\begin{tabular}{cc}
\hline Persentase & Kategori \\
\hline $81-100$ & Sangat Baik \\
$61-80$ & Baik \\
$41-60$ & Sedang \\
$21-40$ & Rendah \\
$0-20$ & Sangat rendah \\
\hline
\end{tabular}




\section{HASIL DAN PEMBAHASAN}

Hasil keterampilan berpikir kritis mahasiswa jurusan komputer terlihat pada Tabel 4.

Tabel 4 Hasil Keterampilan Berpikir Kritis Mahasiswa

\begin{tabular}{lcc}
\hline \multicolumn{1}{c}{ Indikator } & Persentase (\%) & Kategori \\
\hline $\begin{array}{l}\text { Memberi penjelasan sederhana (elementary } \\
\text { clarification) }\end{array}$ & 50,4 & Sedang \\
$\begin{array}{l}\text { Membangun keterampilan dasar (basic } \\
\text { support) }\end{array}$ & 56,0 & Sedang \\
$\begin{array}{l}\text { Menarik kesimpulan (inference) } \\
\text { Membuat penjelasan lebih lanjut (advance } \\
\text { clarification) }\end{array}$ & 39,0 & Rendah \\
$\begin{array}{l}\text { Strategi dan taktik } \\
\text { (strategy and tactic) }\end{array}$ & 25,0 & Rendah \\
\multicolumn{1}{c}{ Rata-Rata } & 33,0 & Rendah \\
\hline
\end{tabular}

Hasil keterampilan berpikir kritis mahasiswa diuraikan berdasarkan pada indikator sebagai berikut. Hasil untuk indikator "memberi penjelasan sederhana" terlihat bahwa saat mahasiswa memberikan penjelasan yang sederhana seperti mengungkapkan fakta yang ada, 38 mahasiswa mengisi pada skala diatas 3 dan 59 mahasiswa mengisi pada skala dibawah 3 serta 18 mahasiswa mengisi pada skala 3. Secara keseluruhan, indikator "memberi penjelasan sederhana" memperoleh nilai sebesar 50,4\% pada kategori sedang.

Hasil untuk indikator "membangun keterampilan dasar" terlihat bahwa ketika mahasiswa memeriksa keakuratan data dengan berbagai sumber yang berbeda, 55 mahasiswa mengisi pada skala dibawah 3, 32 mahasiswa mengisi pada skala 3, dan 29 mahasiswa mengisi pada skala diatas 3. Secara keseluruhan, indikator "membangun keterampilan dasar" memperoleh nilai sebesar 56,0\% dengan kategori sedang. Perolehan nilai dengan kategori sedang pada indikator "membangun keterampilan dasar" mendukung hasil penelitian terdahulu yang menyatakan bahwa keterampilan berpikir kritis mahasiswa tergolong sedang (Ariyatun dan Octavianelis, 2020).

Hasil untuk indikator "menarik kesimpulan" terlihat bahwa kemampuan mahasiswa masih tergolong rendah dengan nilai sebesar 39,0\%. 85 mahasiswa 
mengisi pada skala dibawah 3, yang mengisi diatas tiga hanya 2 orang sementara yang mengisi pada skala tiga 28 mahasiswa. Keterampilan menarik kesimpulan dan inferensi merupakan kemampuan mahasiswa untuk menguraikan dan menarik kesimpulan (Seventika, dkk., 2018). Kemampuan tersebut sangat penting untuk dimiliki oleh setiap mahasiswa untuk memahami dan memaknai materi pembelajaran dengan baik sehingga learning outcome dari pembelajaran tercapai.

Hasil untuk indikator "membuat penjelasan lebih lanjut" terlihat bahwa mahasiswa kesulitan dalam memberikan penjelasan lebih lanjut terhadap data yang telah diperoleh serta menyimpulkan permasalahan dari sudut pandang yang berbeda, hal tersebut sesuai dengan perolehan nilai sebesar $25,0 \%$ pada kategori rendah. Sedangkan hasil untuk indikator "strategi dan taktik" terlihat bahwa kemampuan yang dimiliki oleh mahasiswa masih tergolong rendah dengan perolehan nilai sebesar 33,0\%, mahasiswa kurang mampu untuk memberikan alternatif stategi dalam menyelesaikan sebuah permasalahan.

Keterampilan berpikir kritis yang tinggi dapat meningkatkan kemampuan akademik dan keingintahuan mahasiswa terhadap sesuatu sehingga mahasiswa dapat dengan mudah menemukan solusi dari permasalahan yang sedang dihadapi. Keterampilan berpikir kritis dapat meningkatkan percaya diri dan kemandirian mahasiswa dalam menyelesaikan permasaahan dengan bijak (Adi dan Junining, 2013). Keterampilan berpikir kritis yang rendah atau sedang dapat menyebabkan mahasiswa kesulitan dalam memahami materi pembelajaran secara holistik.

Pengetahuan dan keterampilan mahasiswa hanya terbatas pada materi pembelajaran yang diberikan oleh dosen sehingga mahasiswa tidak terlatih untuk untuk berpikir tingkat tinggi (higer order thinking skils). Rendahnya keterampilan berpikir kritis tidak hanya menyebabkan kesulitan mahasiswa untuk memahami pengetahuan, namun mahasiswa juga mengalami kendala dalam menghadapi ujian dan memecahkan masalah kehidupan sehari-hari. Keterampilan berpikir kritis yang tergolong rendah dan sedang dapat memengaruhi kemampuan mahasiswa untuk memilih profesi yang tepat di masa depan (Aizikovitsh-Udi dan Cheng, 2015). 
Hasil keterampilan berpikir kreatif mahasiswa jurusan komputer terlihat pada Tabel 5.

Tabel 5 Hasil Kemampuan Berpikir Kratif Mahasiswa

\begin{tabular}{lcc}
\hline \multicolumn{1}{c}{ Indikator } & Persentase (\%) & Kategori \\
\hline Keterampilan berpikir lancar & 40,0 & Rendah \\
Keterampilan berpikir luwes (fleksibel) & 44,7 & Sedang \\
Keterampilan berpikir orisinil & 24,0 & Rendah \\
\hline \multicolumn{1}{c}{ Rata-Rata } & $\mathbf{3 6 , 2}$ & Rendah \\
\hline
\end{tabular}

Keterampilan berpikir kreatif juga sangat dibutuhkan pada era Revolusi Industri 4.0. Hasil keterampilan berpikir kreatif mahasiswa dilihat dari berbagai aspek sesuai dengan indikatornya. Hasil keterampilan kreatif untuk berpikir secara lancar menunjukkan bahwa mahasiswa agak kurang terlatih dalam mencetus gagasan maupun memberikan ide terhadap penyelesaian sebuah permasahan. Hal tersebut terlihat dari sebaran nilai yang diperoleh melalui kuisioner, 74 mahasiswa mengisi dibawah 3, sedangkan yang mengisi diatas 3 berjumlah 8 mahasiswa, selebihnya memilih jawaban 3. Secara keseluruhan hasil keterampilan berpikir secara lancar mahasiswa sebesar $40,0 \%$ pada kategori rendah. Sementara untuk keterampilan berpikir luwes (fleksibel) memperoleh nilai sebesar 44,7\% pada kategori sedang, mahasiswa sudah mulai mampu untuk membahas dan mendiskusikan suatu masalah dan menjadi andalan dalam kelompoknya. Fleksibilitas menunjukkan berbagai cara yang diberikan mahasiswa sehingga mengacu kepada jawaban berbeda dan merupakan kombinasi dari pengetahuan yang diperoleh mahasiswa sebelumnya (Endang, 2012). Fleksibilitas sangat dibutuhkan mahasiswa untuk dapat menghasilkan sebuah inovasi dalam pembelajaran.

Berpikir orisinil juga diperlukan mahasiswa, namun mahasiswa masih kesulitan dalam memiliki cara tersendiri yang berbeda dengan teman dalam menyelesaikan sebuah permasalahan, hal tersebut terlihat dari hasil kuisioner yang menunjukkan sebanyak 67 mahasiswa memilih dibawah 3, 22 mahasiswa yang mengisi diatas 3, dan 26 mahasiswa memilih 3. Secara keseluruhan rata-rata 
perolehan nilai untuk indikator beterampilan berpikir orisinil sebesar 24,0\% pada kategori rendah. Kategori rendah pada keterampilan berpikir kreatif bagi mahasiswa memperlihatkan bahwa tidak ada pengaruh peringkat akademik tinggi, sedang, dan rendah dalam pembelajaran (Nurhamidah, dkk., 2018; Sugiyanto, dkk., 2018).

\section{SIMPULAN}

Berdasarkan hasil penelitian, maka dapat disimpulkan bahwa keterampilan berpikir kritis mahasiswa jurusan komputer tergolong rendah pada indikator memberikan penjelasan lebih lanjut dan menarik kesimpulan. Sedangkan untuk keterampilan berpikir kreatif mahasiswa jurusan komputer untuk berpikir secara lancar dan orisinil masih rendah.

\section{DAFTAR PUSTAKA}

Adi, S. S. \& Junining, E. 2013. Kemampuan Berpikir Kritis dalam Membaca serta Kesesuaiannya dengan Intelegensi Mahasiswa Program Studi Sastra Inggris. Erudio, 2(1): 59-64.

Aizikovitsh-Udi \& Cheng. 2015. Mengembangkan Keterampilan Berpikir Kritis dari Disposisi ke Kemampuan: Pendidikan Matematika dari Anak Usia Dini hingga SMA. Kreatif Pendidikan, (6): 455-462.

Ariyatun \& Octavianelis, D. F. 2020. Pengaruh Model Problem Based Learning Terintegrasi STEM terhadap Kemampuan Berpikir Kritis Siswa. Journal of Educational Chemistry, 2(1): 33-39.

Arpan, M. \& Marpanaji, E. Faktor-Faktor Eksternal yang Memengaruhi Hasil Belajar Pemrograman Komputer Mahasiswa PTIK STKIP PGRI Pontianak. Jurnal Pendidikan Vokasi, 5(2): 195-208.

Aun, S. \& Kaewurai, W. 2017. Instructional Model Development to Enhance Critical Thinking and Critical Thinking Teaching Ability of Trainee Students at Regional Teaching Training Center in Takeo Province, Cambodia. Kasetsart Journal of Social Sciences, 38(1): 88-95.

Carrasco, A. 2017. Assessing Creativity to Boost the Inclusion in Musical Education. Artseduca, 16(1): 32-48.

Chu, S. K. W., Reynold, R. B., Tavares, N. J., \& Notari, M. 2017. 21st Century Skills Development Through Inquiry-Based Learning from Theory to Practice. Singapore: Springer.

Endang, K. 2012. Kreativitas Siswa dalam Memecahkan Masalah Matematika Divergen Berdasarkan Kemampuan Matematika Siswa. MATHEdunesa, 1(1): 3-11. 
Fatmawati, B. 2016. The Analysis of Students Creative Thinking Ability Using Mind Map in Biotechnology Course. Jurnal Pendidikan IPA Indonesia, 5(2): 216-221.

Fitriawan, D., Gordah, E. K., \& Dafrita, I. E. 2016. Analisis Korelasi Kemampuan Berpikir Kritis dan Sikap Ilmiah terhadap Prestasi Belajar Mahasiswa. Jurnal Pendidikan Informatika dan Sains, 5(1): 1-11.

Ghanizadeh, A. 2017. The Interplay between Reflective Thinking, Critical Thinking, Self-Monitoring, and Academic Achievement in Higher Education. Higher Education, 74(1): 101-114.

Hairida \& Junanto, T. 2018. The Effectiveness using Inquiry Based Natural Science Module with Authentic Assessment to Improve the Critical Thinking. International Journal of Pedagogy and Teacher Education, 2(7): 159-170.

Harris, A. \& deBruin, L. R. 2018. Secondary School Creativity, Teacher Practice and STEAM Education: An International Study. Journal of Educational Change, 19(2): 153-179.

Husamah, Fatmawati, D., \& Setyawan, D. 2018. OIDDE Learning Model: Improving Higher Order Thinking Skills of Biology Teacher Candidates. International Journal of Instruction, 11(2): 249-264.

Jatmiko, B., Prahani, K., Supardi, Z., Wicaksono, I., Erlina, N., \& Pandiangan, P. 2018. The Comparison of OR-IPA Teaching Model and Problem Based Learning Model Effectiveness of Improve Critical Thinking Skills of PreService Physics Teachers. Journal of Baltic Science Education, 17(2): 1-22.

Lin, C., Li, B., \& Wu, Y. J. 2018. Existing Knowledge Assets and Disruptive Innovation: The Role of Knowledge Embeddedness and Specificity. Sustainability, 10(342): 1-15.

Lucas, B. 2016. A Five-Dimensional Model of Creativity and Its Assessment in Schools. Applied Measurement in Education, 29(4): 278-290.

Mahanal, S., Zubaidah, S., Bahri, A., \& Dinnuriya, M. 2016. Improving Students' Critical Thinking Skills Through Remap NHT in Biology Classroom. AsiaPacific Forum on Science Learning and Teaching, 17(1): 1-19.

Munandar, U. 2009. Mengembangkan Bakat dan Kreativitas Anak Sekolah. Jakarta: Gramedia.

Nurhamidah, D., Masykuri, M., \& Dwiastuti, S. 2018. Profil Siswa Sekolah Menengah Atas Keterampilan Berpikir Kreatif pada Materi Biologi di Akademik Rendah, Sedang, dan Tinggi Perspektif. Jurnal Fisika: Conf. Seri. Penerbitan TIOPenuntun Bagi Guru dan Orang Tua. Jakarta: Grasindo.

OECD Publishing. 2019. PISA 2018 Insights and Interpretations. PISA: OECD Publishing.

OECD Publishing. 2016. PISA 2015 Result in Focus. PISA: OECD Publishing.

OECD. 2014. PISA 2012 Results: What Students Know and Can Do-Student Performance in Mathematics, Reading and Science. PISA: OECD Publishing.

OECD. 2010. PISA 2009 Results: Learning Trends: Changes in Student Performance Since 2000 (Volume V). PISA: OECD Publishing. 
Prahani, B. K., Suprapto, N., Suliyanah, Lestari, N. A., Jauhariyah, M. N. R., \& Admoko, S. 2018. The Effectiveness of Collaborative Problem Based Physics Learning (CPBPL) Model to Improve Student's Selfconfidence on Physics Learning. Journal Physics: Conference Series, 997(08): 1-6.

Rashid, T. \& Muhammad, H. 2016. Penggunaan Teknologi, Keterkaitan Komputer dan Perilaku Manusia, Jurnal Teknodik, 19(1): 1-11.

Ridwan. 2010. Dasar-Dasar Statistika. Bandung: Alfabeta.

Septianawati, D. 2019. Kemampuan Berpikir Kreatif Siswa SMP se-Kota Pontianak. Edukasi: Jurnal Pendidikan, 17(1): 38-46.

Seventika, S. Y., Sukestiyarno, Y. L., \& Marianti, S. 2018. Critical Thinking Analysis Based on Facione (2015) - Angelo (1995) Logical Mathematics Material of Vocational High School (VHS). Journal of Physics: Conf. Series, 983(2018) 012067: 1-6.

Sing, C. \& Kong, C. S. 2017. Professional Learning for 21st Century Education. Journal of Computers in Education, 4(1): 1-4.

Singh, R. M. 2018. Educational Challenges in 21st Century and Sustainable Development. Journal of Sustainable Development Education and Research, 2(1): 9-20.

Sripongwiwat, S., Bunterm, T., Srisawat, N., \& Tang, K. N. 2016. The Constructionism and Neurocognitive-Based Teaching Model for Promoting Science Learning Outcomes and Creative Thinking. Asia-Pacific Forum on Science Learning and Teaching, 17(2): 1-33.

Sugiyanto, F. N., Masykuri, M., \& M. 2018. Analysis of Senior High School Students' Creative Thinking Skills Profile in Klaten Regency. IOP Conf. Series: Journal of Physics: Conf. Series 1006 (2018) 012038: 1-5.

Suprapto, N. 2016. What Should Educational Reform in Indonesia Look Like? Learning from the PISA Science Scores of East-Asian Countries and Singapore. Asia-Pacific Forum on Science Learning and Teaching, 17(1): $1-21$.

Suyidno, S., Nur, M., Yuanita, L., \& Prahani, B. K. 2017. Validity of Creative Responsibility Based Learning: An Innovative Physics Learning to Prepare the Generation of Creative and Responsibility. Journal of Research \& Method in Education, 7(1): 56-61.

Taleb \& Chadwick. 2016. Enhancing Students Critical Thinking Skill and Analitycal Thinking Skill at the Higher Education Level in Developing Countries:Case Study inDubai. Journal of Education and Instructional Studies in the World, 6 (1): 1-8.

Tan, C. 2017. Teaching Critical Thinking: Cultural Challenges and Strategies in Singapore. British Educational Research Journal, 43(5): 988-1002.

Welter, M. M., Jaarsveld, S., \& Lachmann, T. 2017. Problem Space Batters: The Development of Creativity and Intelligence in Primary School Children. Creativity Research Journal, 29(2): 125-132. 